\title{
FACTORS AFFECTING SOCIALIZATION FROM THE PERSPECTIVE OF THE STUDY OF A SCHOOL CHILD
}

\author{
Elżbieta Napora \\ Jan Długosz University in Częstochowa, Poland
}

\begin{abstract}
The aim was to observe factors which favour or hinder socialization of a child age 11-13. 192 pupils from 10 Polish schools were researched, with the use of a classical sociometric J. Moreno test. The results revealed that the analyzed factors: sex and age of a child as well as structure and material status of a family, number of siblings and place of living do not have a clear influence on the socialization of a school-aged child.
\end{abstract}

Keywords: peer group, socio-demographic factors.

\section{Introduction}

In literature there is a lot of evidence to support the thesis that both family and a peer group are wonderful places to influence children and teenagers. Scientists underline the fact that social environment in which the children stay has far-reaching consequences for their proper development. The quality of family environment plays an important role in development and maintenance of a good relationship of a child with peers (Napora \& Pękala, 2014). The researchers observed the connection between a beneficial evaluation of a material situation of a family and the higher sense of security, love and understanding declared by children (Kwak, 2008-2009). Lack of one or both parents, divorce, alcoholism, family criminality, unemployment, poverty (Bradshaw, 1994, p. 81) decreases a child's attractiveness among peers.

Poverty is understood as circumstances which limit the participation of an individual in social life and lead to his exclusion (Balcerzak-Paradowska, 2004, p. 115). Incomplete families are in a difficult situation. $13.7 \%$ of them are at risk of extreme poverty. Families with one child are in a better situation. Research suggests that together with the increase of children in a family, the percentage of people at risk of privation increases, and this situation concerns families mainly from rural areas (Falkowska \& Telusiewicz-Pacak, 2013, p. 47). In 2011 about $60 \%$ of all divorces concerned families with children. It is important as divorce is connected with changes in the previous lifestyle but also with the weakening of parental bonds (Falkowska \& Telusiewicz-Pacak, 2013). It very often leads to the decrease in the standard of life and limits the possibilities of fulfilling one's mental needs. Privation influences interpersonal relations; it releases stress and aggression (Cudak, 2013, p. 10). Weakened emotional bonds in a family with a low material status weaken parents' authority and children's relationships with peers (Napora \& Pękala, 2014). Children from these families have no motivation 
to learn, they are often dominated by the need of possessing material goods (Cudak, 2013).

Attractiveness among peers is the quality which escalation can be described on a one-dimensional-continuum: on the one extreme there are the children who are accepted by a group and on the other - the rejected ones. Recently it has been established that unpopular children can be described as the ones who belong to two categories: rejected and isolated (Dodge et al., 2003). Popularity of children in a group can be marshaled in a scale from the ones who are recognized and liked by the group, through the average ones who maintain closer contacts with a few people, usually liked by the group, to the ones who live on the margin of a group, who are isolated or rejected by others (Paw, 2015) (www.szkolnictwo.pl).

Thanks to the relations with peers, children develop interpersonal and intrapersonal relations, connected with cognitive, emotional and behavioral functioning. At the age of 11-13 a child increases the ability of logical thinking which makes it that he becomes more willing to have a discussion or arguments. At this time the interest in the world of internal experiences increases as well as the tendency to introspection, development of auto-reflection, realization of positive and negative personality features and their impact on behaviour (Niebrzydowski, 1976). Children who are rejected have difficulties with forming interaction with peers, they have a tendency to avoid contacts with others, and they rarely emphasize their rights. Depression symptoms, anxiety and low feeling of social competence can appear (Schaffer, 2006). These children are often described as shy and taciturn. Among the rejected ones, in terms of sex, boys are more often described as the aggressive and annoying (Napora \& Garbiec, in print).

Scientists emphasize that the level of a pupil's acceptance among peers in a class depends not only on progress in learning, comradeship, level of mental development, after-class activeness (Sendyk, 2001), but also on conditions which are beyond the individual such as prosperity and educational climate of a family, parents' education, the number of siblings (Sikorski, 2000 p. 8). The aim was to observe personal and family traits which support or hinder socialization of a child in a school age. The research problem was limited to two questions: 1) what are the proportions of children's attractiveness among peers? 2) which of the analyzed personal features (sex, age of a child) and family (family structure, place of living, the number of siblings, material status of a family) supports socialization of a child and which of the factors limit it?

\section{Material and Methods}

The researched people 192 children age 11-13 took part $(\mathrm{AA}=11.9 ; \mathrm{SD}=$ 0.82). They all come from Polish schools. The tests had been earlier arranged with the headmasters and class teachers. Children were assured of the anonymity of the results and the possibility to withdraw from the research at any time 
without any consequences. Parents had been asked for the approval for their children to take part in the research. Both children and parents were informed about the purpose of the research, research problems and expected benefits. In the research group 162 children $(84.4 \%)$ of children came from full families and $30(15.6 \%)$ from single-mother families. 38 children $(19.8 \%)$ of children described their material status as a very good one, 125 people $(65.1 \%)$ described this status as a sufficient one and 29 of the researched (15.1\%) decided that they were dissatisfied with their material situation. It means that that the majority of the researched children evaluated their material situation as a less satisfying one. Personal data allowed to define the number of siblings. There were $36(18.8 \%)$ of only-children, 126 pupils $(65.7 \%)$ had one brother or sister and 30 children $(15.5 \%)$ had two or more siblings. 105 girls $(54.7 \%)$ and $87(45.3 \%)$ of boys took part in the research.

Tools Sociometry allows to define mutual likes and dislikes, popularity or lack of it, and it enables to distinguish features and qualities connected with comradeship, attractiveness and leadership in a group (Brzeziński, 1980). It is used to establish a pupil's position in a class and recognize social relationships in a group. The classical socio-metric J.L. Moreno test was used. Apart from the personal information ${ }^{1}$, it consisted of six questions which take into account three socio-metric criteria of choice ${ }^{2}$. The task of each pupil was to make positive and negative choices for each criterion among peers from a school class. On the basis of the results three types of socio-metric positions of the researched children were differentiated: with high attractiveness $(n=77 ; 40.1 \%$ of pupils were counted to this group with a big amount of positive choices and a low amount of negative ones), with the average ( $\mathrm{n}=54 ; 28.1 \%$ of children with more or less the same number of positive and negative choices) and the unattractive children $(\mathrm{n}=61 ; 31.8 \%$ of children with a big amount of negative choices and low amount of positive ones).

\section{Results and Discussion}

The analysis of the results involved descriptive statistics of the researched variables and it showed the proportions of attractiveness of children, shown by the number of choices by peers from a class. The results are presented in table 1 and chart 1.

\footnotetext{
${ }^{1}$ The question about material status of a family was limited to one closed (later re-coded) question about the subjective evaluation of a material situation of a family with the selection of one of the three answers.

${ }^{2}$ A class teacher asked to make a holiday news-sheet. (1a) Choose three people from the class who you would ask to help you prepare it. Justify why. (1b) Choose three people from the class who you would ask the least willingly to help you prepare a holiday news-sheet. Justify why. Imagine that you are going on a three-day-trip to Cracow. (2a) Choose three people you would like to sit next to on a coach. Justify why. (2b) Choose three people you would least like to sit next to on a coach. Justify why. (3a) Choose three people from the class you would like to live with in one room during your stay in Cracow. Justify why. (3b) Choose three people with whom you would least like to live in one room during your stay in Cracow. Justify why.
} 
SOCIETY. INTEGRATION. EDUCATION. Volume II

Table 1. Descriptive statistics for the children's socio-metric choices

\begin{tabular}{|c|c|c|c|c|c|c|c|c|}
\hline $\begin{array}{c}\text { Socio- } \\
\text { metric } \\
\text { choices }\end{array}$ & \multicolumn{7}{|c|}{ Descriptive statistics } \\
\cline { 2 - 9 } & No. R & AA & Median & Minimum & $\begin{array}{c}\text { Maximu } \\
\mathrm{m}\end{array}$ & $\begin{array}{c}\text { Lower } \\
\text { Quartile }\end{array}$ & $\begin{array}{c}\text { Upper } \\
\text { Quartile }\end{array}$ & SD \\
\hline positive & 192 & 8.822 & 8.000 & 0.00 & 29.000 & 3.500 & 12.000 & 6.610 \\
\hline negative & 192 & 8.723 & 5.000 & 0.00 & 60.000 & 2.000 & 12.000 & 10.881 \\
\hline
\end{tabular}

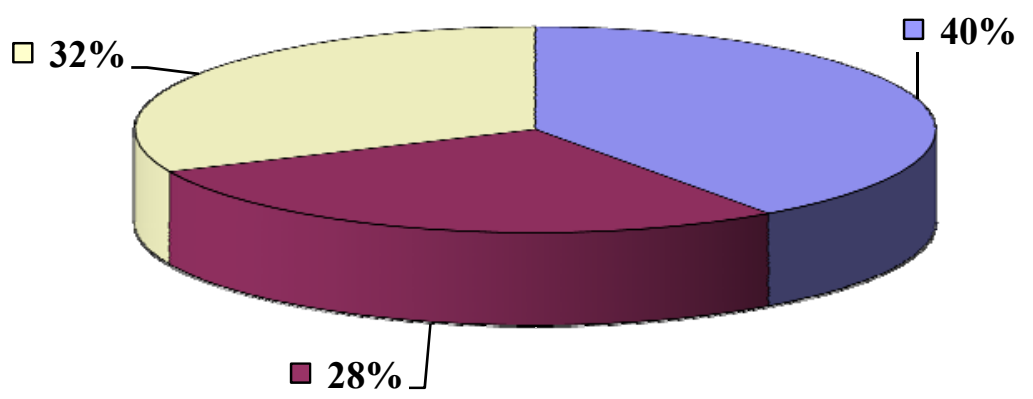

$\square$ Atractive children $\quad \square$ Average attractive children $\quad \square$ Unattractive children

Attractive children $n=77$; average attractive $n=54$; unattractive $n=61$

Figure 1. Proportion of attractiveness of the researched children

Sociodemographic data was correlated with the results from Moreno test showing positive and negative choices expressed towards children by peers from a class. The statistical $U$ Mann-Whitney methods which were used did not reveal significant differences in any of the cases. The effects are presented in charts 2, 3, 4, 5, 6 and 7 .

Sex of a child is a factor which influences the perception of people and activities and it differentiates the opinions of others in a rather significant manner. Hence, this parameter was taken into account. Girls (43.6\%) in comparison with boys $(35.9 \%)$ were more attractive for peers. Sex is without meaning for the unattractiveness in a class (girls $-30.1 \%$, boys $-33.7 \%$ ).

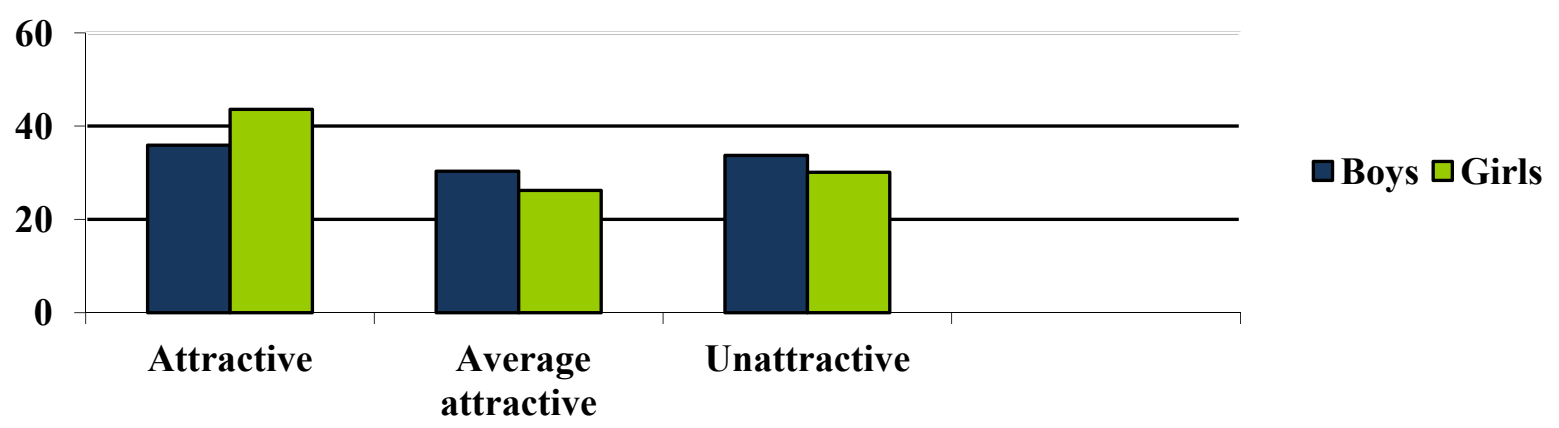

Figure 2. Sex and the attractiveness of children among peers

The age of children was the selection criteria for the examined and its influence on the evaluation of the attractiveness of a child among peers. 
Children aged 11-13 increase their predisposition of logical thinking thanks to which they become willing to have discussions and disputes. Chart 3 shows the distribution of children's attractiveness among peers with the consideration of their age. Effects show that the younger the children are, the more attractive they are among peers ( 11 years old $-40.7 \%, 12$ years old $-44 \%, 13$ years old $35.1 \%)$. On the other hand, the unpopularity of older children increases (11 years old $-28 \%, 12$ years old $-32.2 \%, 13$ years old $-34.2 \%$ ).

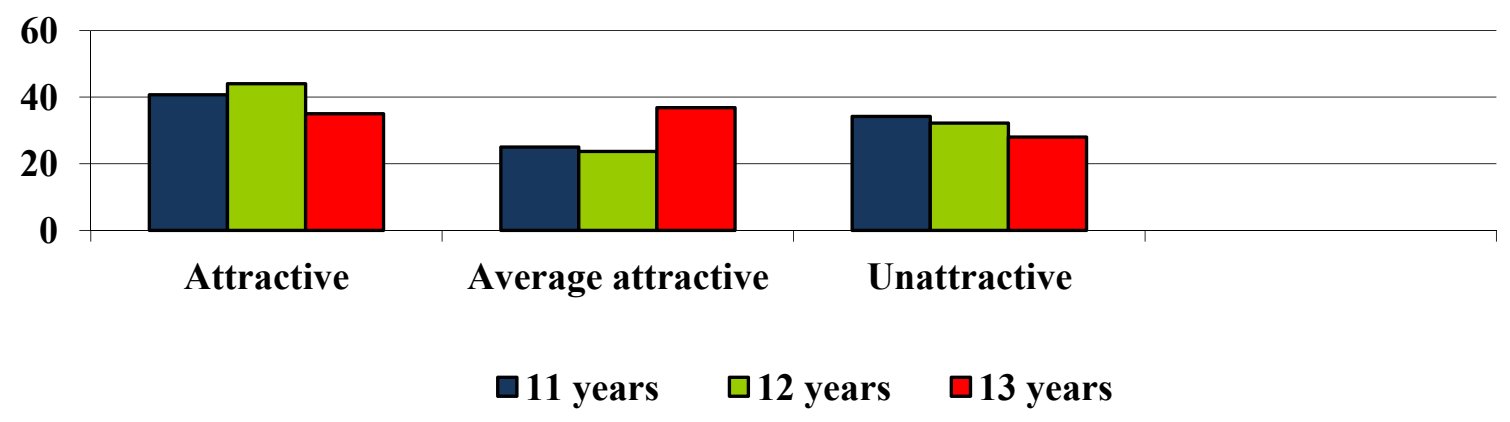

Figure 3. Age of a child and his attractiveness

Family structure Observing the dependency between the attractiveness of children among peers and a family structure were possible thanks to identification of two groups: children from full families and children from incomplete families. During the analysis of the research material collected in the second identified group of children, only these who come from single-mother families were taken into account. Chart 4 shows that $41.9 \%$ of children from a full family were evaluated by their peers as the attractive ones; this assessment was shared by $30 \%$ of children from single-mother families. A different tendency might be observed in the case of the assessment of the average accepted children: $36 \%$ of them come from single-mother families and $26.5 \%$ of them from full families. Comparable data concern unaccepted children: $31.4 \%$ come from full families and 33\% from single-mother families.

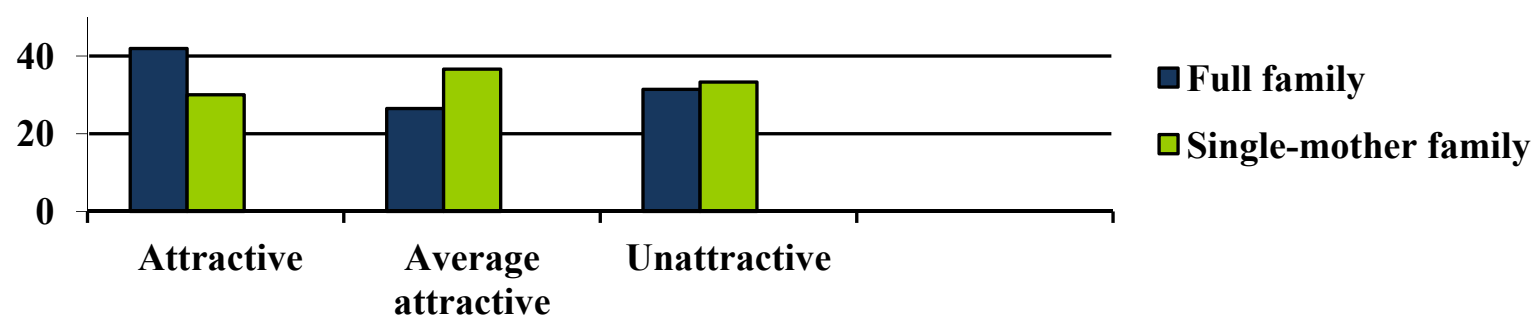

Figure 4. Family structure and children's attractiveness

Material status of a family Family's wealth influences the attractiveness of a child in a group. The highest percentage of unattractive children $-58.9 \%$ come from wealthy families, $37.9 \%$ of children from families with adequate status, and $24.1 \%$ from families with the unsatisfying level of life. The opposite of 
proportions reveals the analysis of unattractiveness of children among peers, i.e. $51.7 \%$ of children come from families with the unsatisfying status, $30.6 \%$ from the ones with a satisfying status and $20.5 \%$ from the well-off families. The effects of the analysis are shown in chart 5.

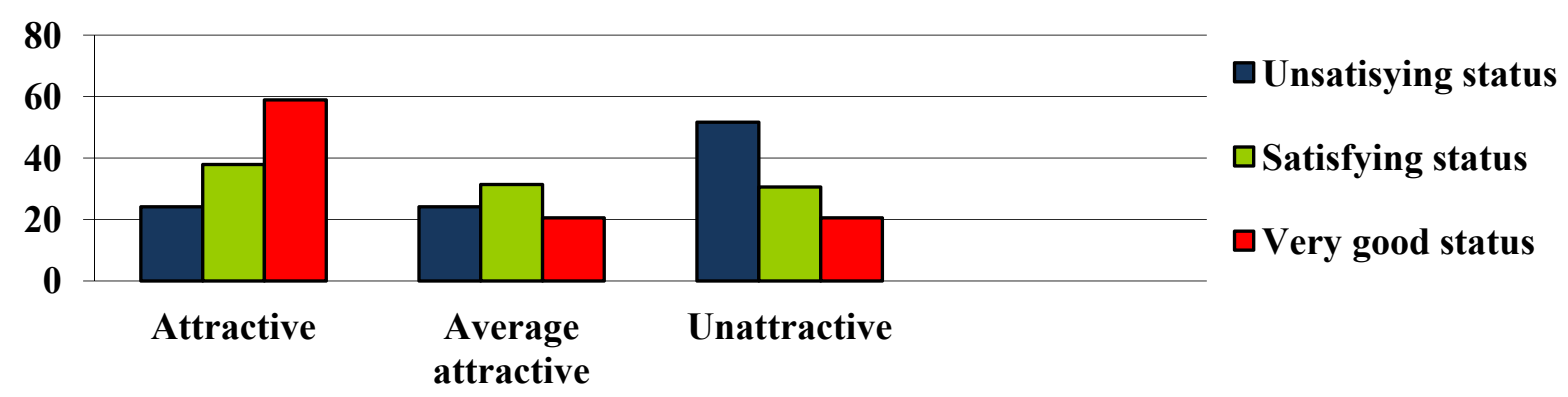

Figure 5. Material status of a family and children's attractiveness

Number of siblings Chart 6 shows the differentiation of children's popularity among peers in terms of the number of siblings. Children like their peers who have more than one brother or sister $43.6 \%$; the least attractive are the children from large families (more than three siblings). Different proportions are observed while analyzing data concerning lack of attractiveness: $36.6 \%$ of children from large families, $30.5 \%$ of only children and the same number with one or two siblings.

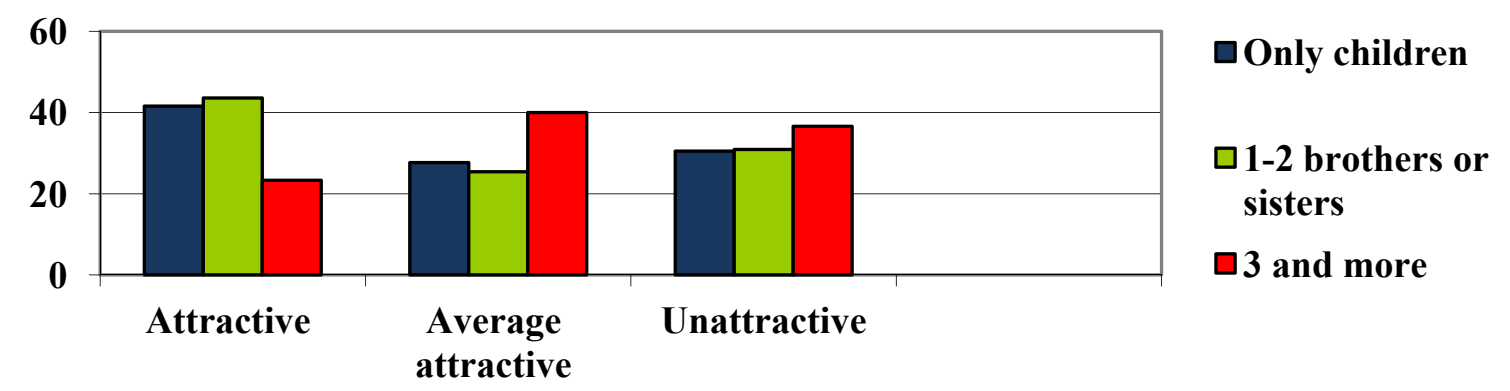

Figure 6. The number of siblings and children's attractiveness

The family's place of living Children both from a village (40\%) and from cities (40.2\%) are equally attractive among peers. A similar tendency is observed in terms of unattractiveness $-30.9 \%$ of children from a village; $32.9 \%$ of children from a city.

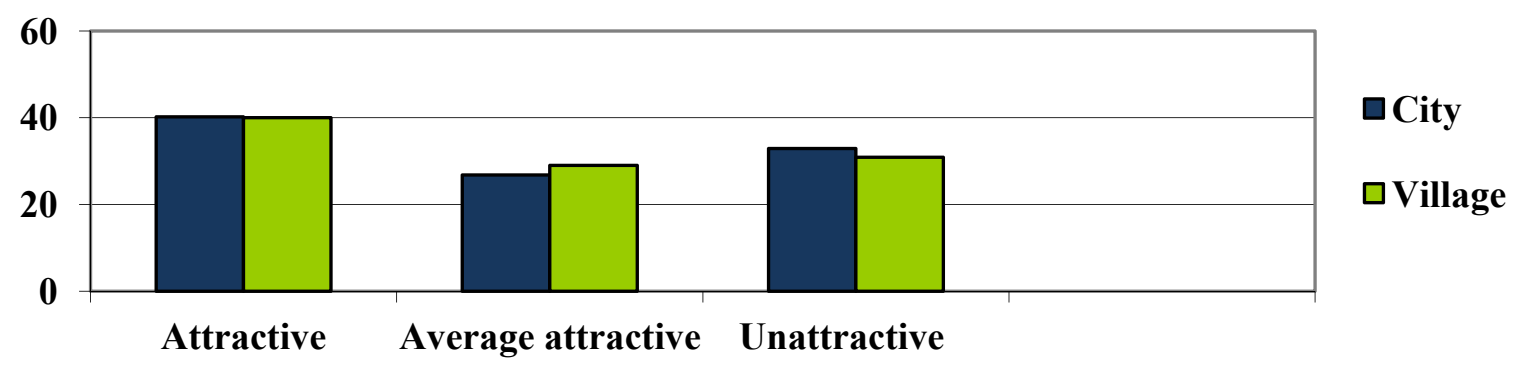

Figure 7. Place of living and children's attractiveness 
The aim of the research was to observe personality and family traits which support or impede socialization of school-aged children. The first research problem concerning the proportion of attractiveness of children among peers can be answered by stating that attractive children are the dominant ones (chart 1). They are seen as friendly people and they show positive behaviour towards themselves.

Answering the second question, which of the analyzed personal features (sex, age of a child) and family ones (structure and material status of a family, number of siblings, place of living) support the socialization of a child and which significantly hinder it; it can be said that no difference which is statistically significant was observed. It suggests that analysis of single factors did not reveal significant changes and only allowed to observe some tendencies. A child's place of living supports socialization of a child (chart 7) - children experience popularity or the lack of it in a similar way (30.9\% of children from a village and $32.9 \%$ of children from a city). This result contradicts the research carried out by Kozerska (2010) in which the author observed difficulties with adaptation of the researched who come from a village to the requirements of a school in a city which they attend. Moreover, sex of a child (chart 2) - girls in comparison with boys are more attractive for peers; number of siblings (chart 6 ) - children who have more than one brother or sister are more popular. Yet a family structure does not have a significant influence on the unattractiveness of a child in a group (chart 4 ).

The observed tendencies revealed that children who suffer from poverty are exposed to lack of acceptance from friends and they tend to have problems with making and maintaining satisfying relationships with friends (chart 5). A lot of children feel bad in the school class $(51.7 \%)$ and a lot of them experience negative attitude of friends from a class towards them. Most of them, however, have friendly relationship with chosen peers, who are mostly also poor. Children from well-off families are unwilling to develop close relationships with children from poor families and they are not eager to spend free time with them. It suggests that poverty of a family is a highly untypical phenomenon for the development and social adaptation of children. Children who unsatisfactorily evaluate a family well-being are definitely less attractive for their peers. However, in a research conducted without the presence of parents, it is difficult to obtain reliable information concerning family's wealth. Unattractive children are the subject of open antipathy of a group. Being in a group is for them the source of negative experiences. According to Ekiert-Grabowska (1982) it can influence their attitude towards school, motivation to learning, evaluation of one's own self.

Additionally, the effects revealed that child's attractiveness among peers (chart 3) worsens he gets older. The younger the children are, the more attractive they are among peers. Among the older ones, this lack of popularity can result 
from a more critical observation of the relations with others (Borecka-Biernat, 2006), or from revealing anti-social and aggressive behaviour.

Development of social competence in a group enables better understanding of social situations, it increases knowledge about social phenomena, develops social deduction and it is a training of social roles (Harwas-Napierała \& Trempała, 2006). For a school-aged child, peer opinions are very important. The frequency of contacts with them escalates the mutual liking, increases attractiveness and leads to a child's socialization. A child derided by peers withdraws from relations and his skill of managing in a group decreases.

Studies reveal that the socio-economic situation of parents has an influence on popularity. Children who are more popular among peers come from families which are better financially situated. However, lack of action from the parents' side which aim at eliminating real or potential life and development threats can be the reason of deformation in the child's mentality and it can influence their low position in a peer group.

Individual traits connected with a child and family do not impede socialization of a child in a school age. Hence, a question arises - how personality or family features condition socialization or the lack of it? Moreover, one can hypothesize that less attractive children can be the object of unpleasantness expressed by peers and that these negative experiences can cause problems connected with adaptation.

To sum up, the obtained effects reveal the following tendencies. Personality and family traits which support a child's socialization include sex (girls are more attractive for peers than boys), age (the older the child is, the less attractive he is for peers), number of siblings (not more than two brothers or sisters), family's prosperity (more attractive children come from well-off families). Traits which hinder a child's socialization include poverty and incomplete family. The place of living is without meaning for the popularity of a child in a class. In the context of the obtained results, it is worth to underline that parents and their bond with children become more important than the influence of a family's structure, low income and the number of siblings.

\section{Conclusions}

1. Children both from a village and a city are similarly popular among peers. A similar conclusion concerns children who are unaccepted in a class and who come from families of various structure.

2. With the lowering material status of a family, especially in single-mother families and the increasing number of children in a family, child's attractiveness among peers decreases. 


\section{References}

Balcerzak-Paradowska, B. (2004). Rodzina i polityka rodzinna na przełomie wieków. Warszawa: Instytut Pracy i Spraw Socjalnych.

Borecka-Biernat, D. (2006). Strategie radzenia sobie mtodzieży $w$ trudnych sytuacjach społecznych. Psychologiczne uwarunkowania. Wrocław: Publishing House: Wrocław University.

Bradshaw, J. (1994). Zrozumieć rodzinę. Rewolucyjna droga odnalezienia samego siebie. Warszawa: Instytut Psychologii Zdrowia i Trzeźwości.

Brzeziński, J. (1980). Elementy metodologii badań psychologicznych. Warszawa: PWN.

Cudak, H. (2013). Ubóstwo ekonomiczne rodziny jako ważny paradygmat dysfunkcji środowiska rodzinnego, Pedagogika Rodziny, 3, 7-17.

Dodge, K.A., Lansford, J.E., Burks, V.S., Bates, J.E., Pettit, G.S., Fontaine, R., Price, J.M. (2003). Peer rejection and social information - processing factors in the development of aggressive behavior problems in children. Child Development 74(2), 374-393.

Falkowska, E., Telusiewicz-Pacak, A. (2013). Dzieci w Polsce. Dane, liczby, statystyki. PKN Unicef. Warszawa 2013

Ekiert-Grabowska, D. (1982). Dzieci nieakceptowane w klasie szkolnej. Warszawa: WSiP.

Harwas-Napierała B. \& Trempała J. (2006). (Red.), Psychologia rozwoju człowieka. Charakterystyka okresów życia człowieka. Warszawa: PWN.

Paw, D. (2015). Interakcje a pozycja społeczna dziecka $w$ grupie rówieśniczej. Obtained from: www.szkolnictwo.pl/index.php?id=PU9373 (access 26.01.2015)

Kozerska, A. (2010). The Opinions - of Extra Mural Students about the Factors which Hinder the Study. The New Educational Review, 1, 78 - 89.

Kwak, A. (2008-2009). Młodzież a rodzina. Roczniki Socjologii Rodziny. XIX Rodzina i młodzież. Teoria i badania.

Napora, E. (2015, in print). Poverty of a family from provincial Poland and attractiveness of a school child among peers. Journal of Educational Sciences.

Napora, E., Garbiec, P. (2014). Cechy rodziny i dziecka a jego popularność wśród rówieśników. Badania uczniów ze szkół w prowincjonalnej Polsce. Wychowanie na co Dzień, 4.

Napora, E., Pękala, B. (2014). Wsparcie i komunikacja matek czynnikiem prężności w funkcjonowaniu córek wśród rówieśników. Polskie Forum Psychologiczne, 19(2), 391406.

Niebrzydowski, L. (1976). O poznawaniu i ocenie samego siebie. Warszawa: IW NK

Sendyk, M. (2001). Klasa szkolna jako miejsce doświadczeń społecznych uczniów. Edukacja. Studia. Badania. Innowacje, 2, 56-67.

Sikorski, W. (2000). Struktura cech osobowości uczniów akceptowanych i odrzucanych w klasie szkolnej. Opieka-Wychowanie-Terapia, 3, 8-13.

Schaffer, R.H. (2006). Psychologia dziecka. Warszawa: Wydawnictwo Naukowe PWN. 